http://jmscr.igmpublication.org/home/ ISSN (e)-2347-176x ISSN (p) 2455-0450 crossref DOI: https://dx.doi.org/10.18535/jmscr/v8i8.22

Journal Of Medical Science And Clinical Research

\title{
Prevalence of Hepatitis C Virus Genotypes in Jammu: A Hospital Based Observational Study
}

\author{
Authors \\ Dr Perika ${ }^{1}$, Dr Priyanka Sharma ${ }^{2}$, Dr Shashi Sudhan Sharma ${ }^{3}$, \\ Dr Vijant Singh Chandail ${ }^{4}$, Dr Konika Razdan ${ }^{5}$ \\ ${ }^{1}$ Post Graduate, Department of Microbiology, GMC Jammu \\ ${ }^{2}$ Senior Resident, Department of Microbiology, GMC Jammu \\ ${ }^{3}$ Professor, PI and Nodal Officer, VRDL, Department of Microbiology, GMC Jammu \\ ${ }^{4}$ Associate Professor, Department of Medicine, GMC Jammu \\ ${ }^{5}$ Research Scientist I (Medical) VRDL, Department of Microbiology, GMC Jammu \\ *Corresponding Author \\ Dr Shas hi S Sharma \\ Professor, PI and Nodal Officer, Dept. of Microbiology, GMC Jammu, India
}

\begin{abstract}
Background and Objectives: Hepatitis $C$ Virus $(\mathrm{HCV})$ is an emerging infection in India and one of the major global health issues with an overall prevalence of 1\%, among which 71 million people are living with chronic HCV infection. Every year 1.7 million of hepatic burden is added with an estimated 399,000 deaths. In India, North eastern tribal populations, and areas of Punjab are the major hotspots of HCV infection. HCV has been divided into 8 genotypes, each showing wide variation in their distribution. The present study was designed to estimate the prevalence of various HCV genotypes in Jammu region of $J \& K$ and study the correlation between detected genotypes and clinical presentation.

Materials and Methods: Blood samples of patients attending the Department of Medicine, Government Medical College, Jammu referred to VRDL section, Department Of Microbiology, GMC Jammu for serological testing by anti-HCV ELISA wherein the positive samples were subjected to genotyping.

Results: This study showed that, out of $50 \mathrm{HCV}$ positive patients, 37 (74\%) were positive for genotype 3, $8(16 \%)$ for genotype 1,1 (2\%) for genotype 4 and in 4 (8\%) genotype couldn't be detected.

Conclusion: Jammu region of $J \& K$ has very few reports on the prevalence of HCV infection and hence knowledge of the predominant HCV genotypes is important for better management of chronic HCV infection and also helps clinicians in guiding appropriate antiviral therapy.
\end{abstract}

\section{Introduction}

Hepatitis C Virus (HCV) infection, one of the major global health issues and an emerging infection in India, is one of the important risk factor for Liver cirrhosis (LC), Hepatocellular carcinoma (HCC), and chronic hepatitis (Patel $\mathbf{P H}$ et al., 2017) ${ }^{\mathbf{1}}$. According to World Health
Organisation (WHO), overall prevalence of $\mathrm{HCV}$ infection is estimated to be $1 \%$ of which 71 million people worldwide are living with chronic $\mathrm{HCV}$ infection, with 1.7 million new cases and 399,000 deaths occurring each year (WHO, 2017) ${ }^{2}$. Most common transmission route for $\mathrm{HCV}$ is estimated to be parenteral like Intravenous 
drug abuse, reuse or inadequate sterilization of medical equipment, transfusion of unscreened blood and blood products (Sy T and Jamal MM, 2006) ${ }^{3}$, sexual transmission and mother to child transmission being the less common modes of transmission.

$\mathrm{HCV}$, a small enveloped virus belongs to genus Hepacivirus, family Flaviviridae with a positive sense single stranded ribonucleic acid (ss-RNA) genome. Viral genome has a total length of $9.6 \mathrm{~kb}$ with one open reading frame (ORF) and 5' and 3' untranslated regions (UTRs) at both edges and shows high degree of genetic variability and widespread mutations because of imperfect proof reading ability of viral RNA- dependent RNA polymerase (Ashfaq UA et al., 2011) ${ }^{4}$.

On basis of phylogenetic and sequence analysis of whole viral genome, HCV strains have been classified into 7 major genotypes and a newly detected Genotype 8 (Borgia SM., et al 2018) ${ }^{\mathbf{5}}$ with 67 confirmed and 20 provisional subtypes. Strains belonging to same subtypes differ at $<15 \%$ of nucleotide sites (Smith DB et al, 2014) ${ }^{6}$. The distribution of HCV genotypes is highly variable with Genotype1 being most prevalent in Europe, Genotype 2 in Central Africa and Genotype 3 in India, Pakistan, Bangladesh, Myanmar, Nepal, Thailand and Northern European countries. Genotype 4 is most frequently found in Central Africa and the Middle East, genotype 5 is most common in Southern Africa while as Genotype 6 is the dominant genotype in Laos and Vietnam and is present at the highest frequencies in East and Southeast Asia. Increased prevalence of genotypes 4 and 5 is due to emigration from the Middle East and Africa.

Genotypic distribution of $\mathrm{HCV}$ in India suggests genotype 3 to be commonest (61.8\%), followed by genotype 1 (31.2\%). Genotypes 2, 4, 5, 6 have been detected in $0.05 \%$ to $4.5 \%$ cases (Satsangi $\mathbf{S}$ and Chawla YK, 2016) ${ }^{7}$. Genotype 3 is most common in Northern, Western and Eastern India whereas genotype 1 is common in Southern India. Genotype 4 is recognised as an emerging threat and a cause of chronic liver disease in South India especially from states of Andhra Pradesh, Tamil Nadu and Kerala (Raghuraman $S$ et al., 2004) ${ }^{8}$. In north eastern part of India genotype 6 is exclusively prevalent (Christdas J et al., 2013) 9 . Genotype 2 has rarely been reported from India whereas genotype 5 is yet to be reported. Such epidemiological and trend analysis can help in revolutionizing management of $\mathrm{HCV}$ by introduction of Directly-acting antivirals (DAAs). India, second most populated country after China is a major contributor to global HCV burden, harbouring about 12-18 million HCV infected people, with an estimated prevalence of infection to be $0.5 \%-1.5 \%$ (Barman B et al., 2018) ${ }^{\mathbf{1 0}}$.

The virus genotype does not influence the presentation of the disease, though it is a major predictor of course and severity of disease process. Study of genotypes has clinical significance as it is seen that serum HCV RNA levels are higher in patients infected with $\mathrm{HCV}$ genotype 1 than in those with genotype 2 (Kohara M et al., 1995) ${ }^{11}$. Also, serum HCV RNA levels were found to be reduced to 4 times more in genotype 2 infected patients than in patients infected with genotype 1, thereby determining the type of antiviral drugs to be administered along with the duration, efficacy and response to the treatment (Kumar JP and Puttamaregowda H, 2016) ${ }^{12}$.

Jammu and Kashmir has very few reports about the surveillance of $\mathrm{HCV}$ and being in the neighbourhood of Punjab which is a hot spot of $\mathrm{HCV}$ infection it becomes more important to study the prevalent genotypes of $\mathrm{HCV}$ in this state. Hence, this study was planned to detect prevalent genotypes of $\mathrm{HCV}$ in patients of Jammu region and their association with disease progression which eventually affect the selection of appropriate antiviral therapy.

\section{Materials and Methods}

This research and observational study was conducted over a period of one year i.e. November 2018 to October 2019 at Govt. Medical College Jammu, J\&K, India, a tertiary care teaching 
hospital, after clearance from the Institutional Ethical Committee. Blood samples were received from patients attending medical outpatient department and various wards of the hospital and processed in the Department of Microbiology. $\mathrm{HCV}$ infected patients above 15 years with jaundice, hepatic disease, and deranged liver function tests were included in the study, while those infected with hepatitis B virus, human immunodeficiency virus, and other hepatitis viruses were excluded from the study. Blood samples collected from medicine OPD were referred to VRDL section, Department of Microbiology, GMC Jammu. Serum was separated and samples were subjected to anti$\mathrm{HCV}$ testing by ELISA (Merilisa HCV) as per manufacturer's instructions. Anti- HCV positive samples were included for HCV RNA detection and genotyping studies.

\section{HCV RNA Extraction and Detection}

RNA extraction of anti-HCV positive samples was done by using Lysis buffer extraction method (Tan SC and Yiap BC, 2009) ${ }^{13}$. Extracted RNA was further subjected to agarose gel electrophoresis.

\section{HCV Genoty ping}

Extracted RNA was further subjected to $\mathrm{HCV}$ genotyping using TRUPCR HCV Genotyping kit. Genotyping method consisted of a two step real time reverse transcription PCR assay; RNA templates were first reverse - transcribed to generate complementary c DNA strands followed by DNA polymerase- mediated c DNA amplification.

\section{Results}

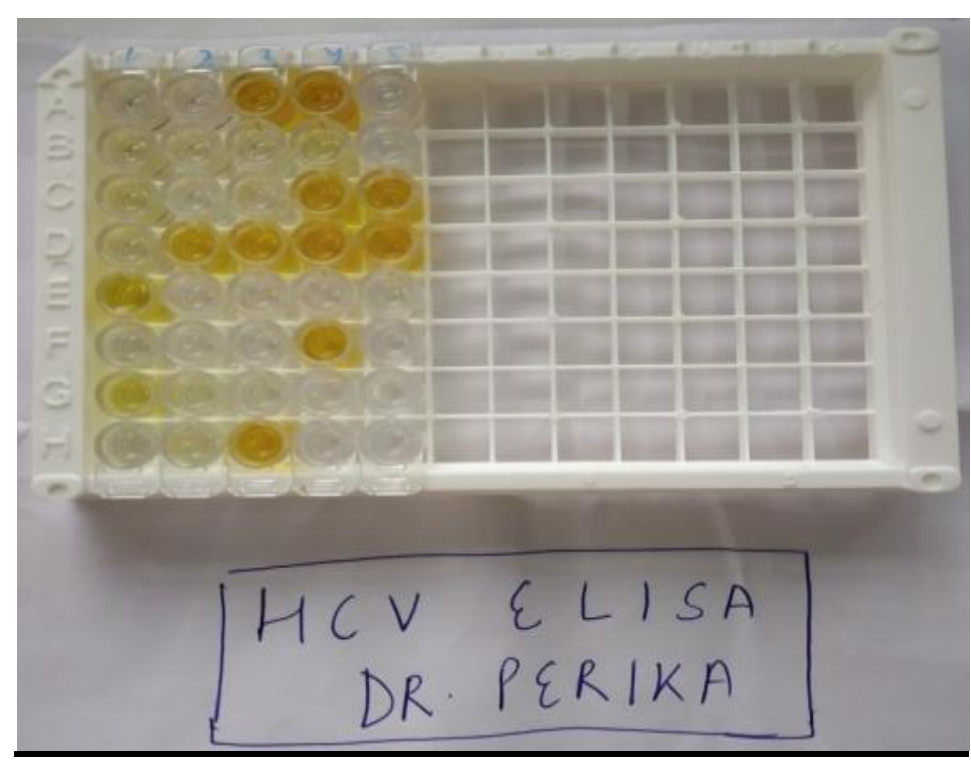

Figure 1: Microtitre plate for anti-HCV ELIS A 


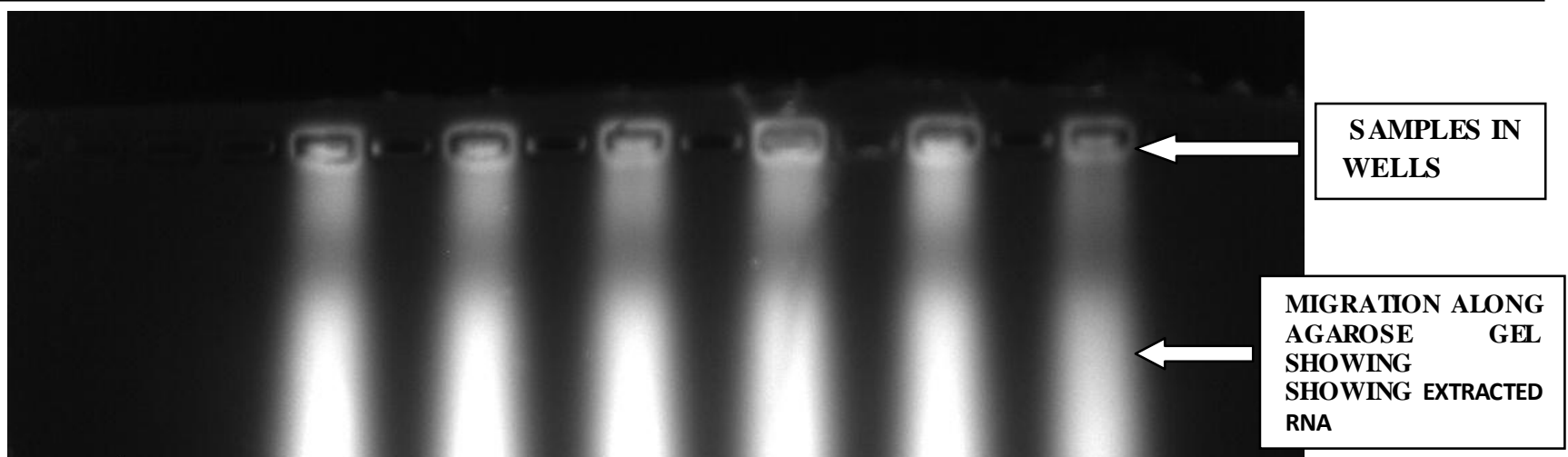

Figure 2: Agarose gel electrophoresis showing RNA extraction

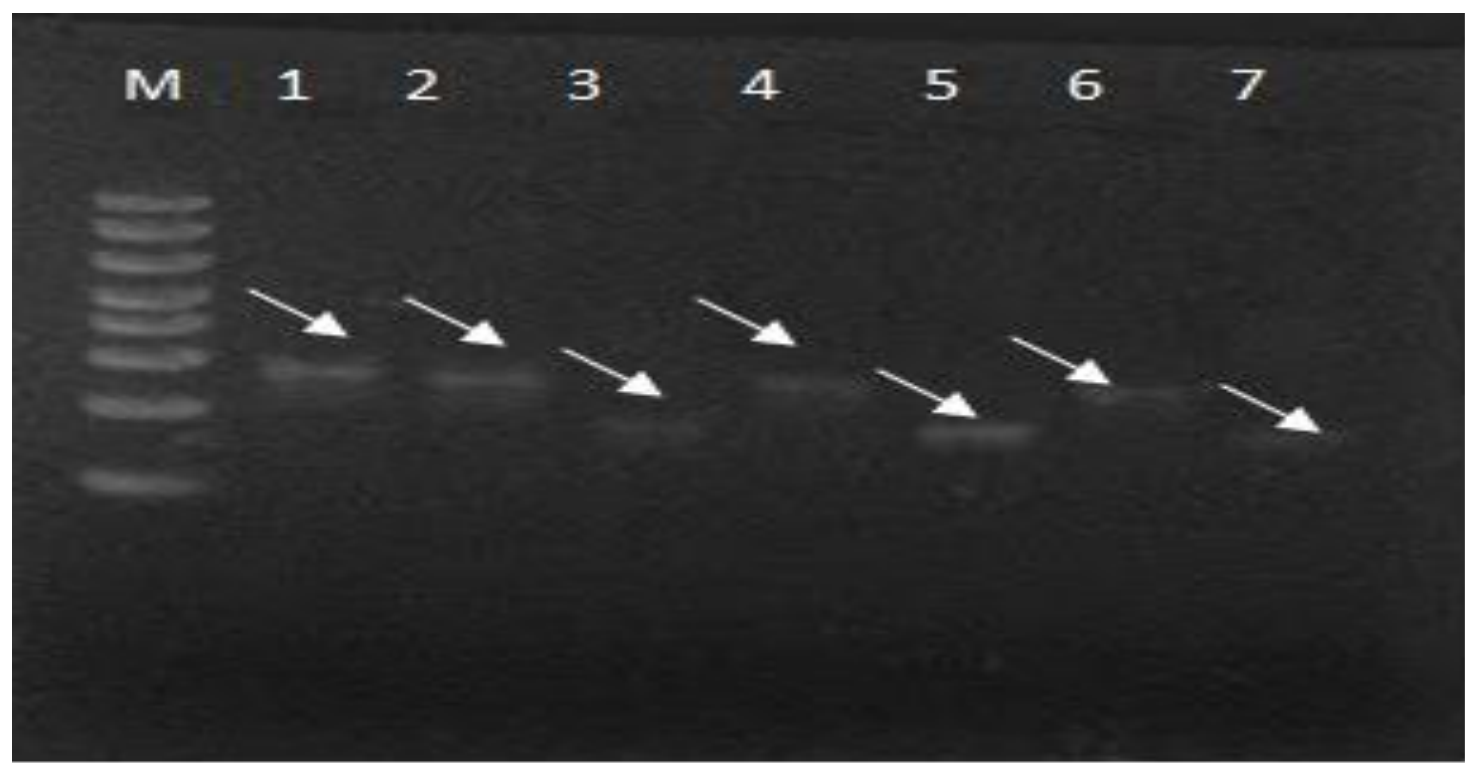

Figure 3: HCV Genotyping Agarose Gel Electrophoresis Results Lanes 1, 2, 4 \& 6 show approximately $260 \mathrm{bp}$ band corresponding to genotype 3 while in wells $3,5 \& 7$ show $\approx 230$ bp bands of genotype 1 .

Among $50 \mathrm{HCV}$ positive patients, 27(54\%) had high viral load values (> 8 lac IU/ml), while $23(46 \%)$ had low viral load (<8 lac IU/ml) (Fig: 4). 


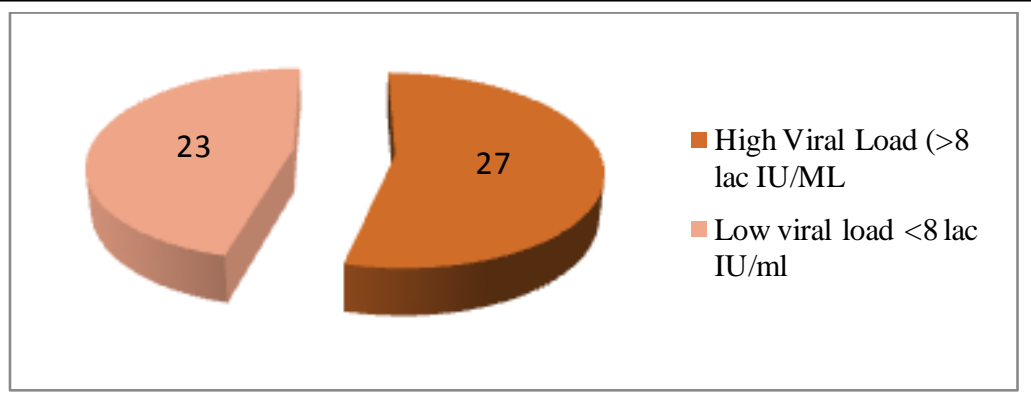

Figure 4: Figure depicting viral load of the infected patients

50 anti-HCV positive samples were subjected to genotyping studies. Most prevalent genotype was Genotype 3, reported in 37(74\%) cases followed by Genotype 1 in $8(16 \%)$. In $1(2 \%)$ cases, genotype 4 was seen and in $4(8 \%)$ cases Genotype was undetected (Fig 5).

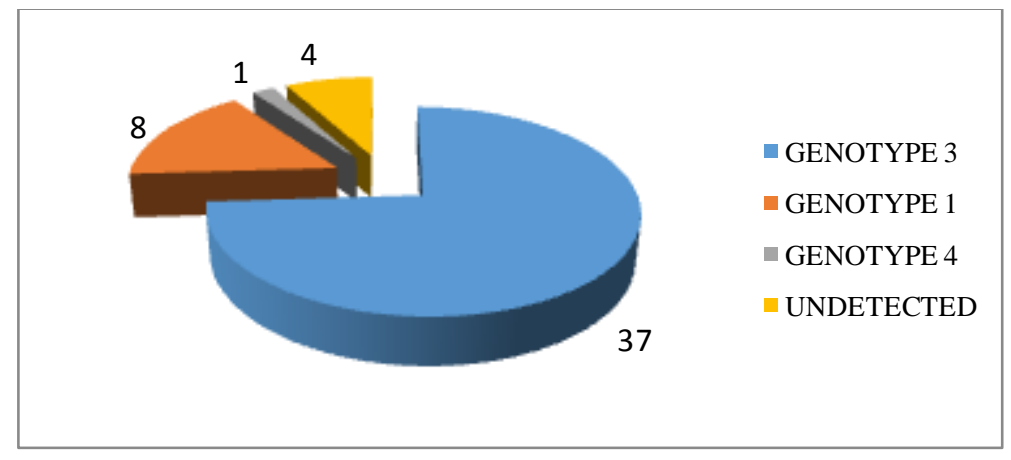

Fig 5: Figure depicting the distribution of genotypes among the infected patients

Among $50 \mathrm{HCV}$ positive patients, 40 (80\%) patients were found to be asymptomatic i.e. they had no sign and symptoms of disease and were diagnosed during routine investigation for operation, blood donation or routine investigation for antenatal checkups etc. While 10 (20\%) patients presented with common symptoms of hepatitis for example pain in right upper quadrant abdomen, vomiting, jaundice etc (Fig 6).

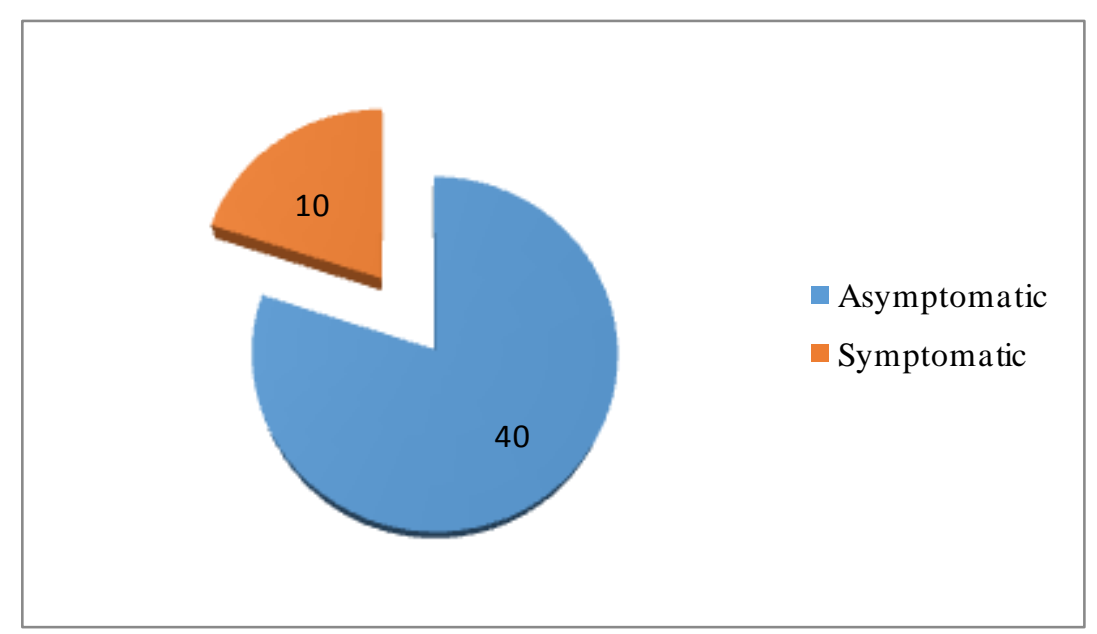

Figure 6: Clinical Profile of the patients

\section{Discussion}

Hepatitis C continues to be a major cause of concern with its hepatic wrath contributing towards a huge burden on public health systems. It is estimated that a minimum of $3 \%$ of the World's population is chronically infected with $\mathrm{HCV}$ 
(Alter MJ, 2007) ${ }^{\mathbf{1 4}}$. Indian Medical Association in a study estimated that nearly 12.5 million Indians suffer from hepatitis $\mathrm{C}$ disease, with the death rate exceeding one lakh per year (Deshpande RH and Wadde SK, 2012) ${ }^{15}$.

A knowledge of $\mathrm{HCV}$ genotyping has gained importance over the years as it has a role in elucidating the therapeutic, prognostic \& clinical status of the HCV infection (Aziz $\mathbf{H}$ et al., 2013) ${ }^{16}$. Therefore, the present study was planned to determine the prevalence of various genotypes in Jammu region which would further help the clinicians in guiding appropriate therapy to control HCV infection.

In the present study, samples were collected from November 2018 to October 2019 from Medicine OPD, GMC Jammu. $5 \mathrm{ml}$ of venous blood was collected from each patient and sent to VRDL, Department of Microbiology, GMC Jammu for further processing. Serum was separated by centrifugation, aliquoted and stored at $-20^{\circ} \mathrm{C}$.

Anti- HCV ELISA confirmed $50 \mathrm{HCV}$ positive patients.

This study showed that, out of $50 \mathrm{HCV}$ positive patients, 37 (74\%) were positive for genotype 3, 8 (16\%) for genotype 1, 1 (2\%) for genotype 4 and in $4(8 \%)$ genotype couldn't be detected. Non detection of Genotype in four patients would be due to low viral load, technical error or the fact that patients were on treatment since longer duration. In a similar study from North India by Sharma $\mathrm{M}$ et al., $\mathbf{2 0 1 7}^{\mathbf{1 7}}$ genotypes 3 and 1 were most commonly found, Chakravarti A et al., $\mathbf{2 0 1 1}^{\mathbf{1 8}}$ also reported genotypes $3(63 \%)$ and 1 $(30.98 \%)$ to be predominant in Delhi. Kumar S et al., $2014^{19}$ reported that HCV genotype 3 is the most common genotype found in North India. Shah NA et al., $2017^{20}$ in a study from Kashmir reported genotype 3 in $90.8 \%$ and genotype 1 in $8.1 \%$ cases. Studies by Al Mahtab M, 2016 ${ }^{21}$, Khan AW et al., 2017 ${ }^{22}$, Chaudhary $S 2018^{23}$, conducted in neighbouring countries of Nepal, Pakistan and Bangladesh have documented genotype 3 to be most prevalent. Contrary to this, Chen Y et al., $2017^{24}$ reported genotype 1
(52.18\%) to be most prevalent in China followed by genotype $2(28.69 \%)$. Findings of our study also correlate with study from South India by Christdas J et al., 2013 $^{\mathbf{9}}$ where genotypes 3 and 1 were documented in $63.85 \%$ and $25.72 \%$ cases respectively. Messina JP et al., $\mathbf{2 0 1 5}^{\mathbf{2 5}}$ from their study concluded that genotype 1 was most prevalent (46.2\%) followed by genotype 3 (30.1\%). Another study in Maharashtra by Mohanraj U et al., $\mathbf{2 0 1 5}^{\mathbf{2 6}}$ reported a rare genotype 5 in $1.25 \%$ cases. Genotype 5 is predominantly found in South Africa. Occurrence of this rare genotype may be because of sporadic cases of transmission of genotypes from other geographical regions, where endemicity of this genotype is higher. Our study has reported a rare genotype- 4 in $2 \%$ of the cases which is in accordance with study by Das BR et al., $\mathbf{2 0 0 2}^{\mathbf{2 7}}$ where genotype 4 was seen in $4 \%$ of the cases. Prakash S et al., 2018 ${ }^{28}$ in a study from Uttar Pradesh reported genotypes 3 and 1 to be most prevalent while genotype 4 was seen in $0.24 \%$ cases. Study by Raghuraman $\mathrm{S}$ et al., $\mathbf{2 0 0 4}^{\mathbf{8}}$ found genotype 4 in $7.2 \%$ cases. Genotype 4 is recognised as an emerging threat and a cause of chronic liver disease in South India especially from states of Andhra Pradesh, Tamil Nadu and Kerala (Raghuraman $\mathbf{S}$ et al., 2004) ${ }^{\mathbf{8}}$. It is hypothesized that mass migration of individuals from South India to oil rich Middle East countries was followed by return of immigrants to India and $\mathrm{HCV}$ genotype 4 may have entered India because of transmission from these returning émigrés (Zachariah $\mathrm{KC}$ et al, 2001, 2002) ${ }^{\mathbf{2 9}}$. In our study one case of genotype 4 was reported. In this region part of a population go to Middle East for better job opportunities and a large number of emigrants come to Jammu from UP and Bihar. Middle East \& UP, Bihar are the hotspots of genotype 4 and this might be attributed for genotype 4 in our case. Study by Barman B et al., $\mathbf{2 0 1 8}^{\mathbf{1 0}}$ in North Eastern region of Meghalaya documented Genotype $3(48.7 \%)$ to be most prevalent followed by genotype 6 (30.8\%). Christdas J et al., $\mathbf{2 0 1 3}^{9}$ reported genotype 6 to 
be exclusively prevalent in North Eastern India. Also, study from Punjab by Borgia SM et al., $\mathbf{2 0 1 8}^{5}$ documented presence of a novel HCV Genotype 8, thus expanding classification of $\mathrm{HCV}$ into 8 genotypes.

The present study showed that $87 \%$ cases of $\mathrm{HCV}$ genotype 1 had high viral load values while in HCV genotype 3, $46 \%$ cases had high viral load values. This is in accordance with study by Chakravarti A et al., 2011 ${ }^{30}$ which showed that genotype 1 had significantly higher viral load than genotype 3 which is attributed to more efficient viral replication of genotype 1 as compared to the others. Rong $\mathrm{X}$ et al., $\mathbf{2 0 1 2}^{\mathbf{3 1}}$ reported that genotype 3 is associated with lowest viral loads while another study by Nabi SG et al., $\mathbf{2 0 1 3}^{\mathbf{3 2}}$ and Rastin $M$ et al., $2014^{33}$ also reported that genotype 1 had high viral load values.

In our study genotypes 3 and 1 were most prevalent whereas similar studies from neighbouring states of Punjab, Haryana, and Delhi have also reported preponderance of $\mathrm{HCV}$ genotypes 3 and 1 . In the neighbouring countries of our region like Nepal, Bangladesh, Pakistan genotypes 3 and 1 were found to be most common. Punjab is an important hotspot of $\mathrm{HCV}$ infection and a growing epidemic of IV drug abuse is an important risk factor for $\mathrm{HCV}$ infection in this region. Therefore, because of geographical niches and travelling to neighbouring countries could be the reason for detection of genotypes 3 and 1 in Jammu region.

\section{Conclusion}

$\mathrm{HCV}$ is a major cause of morbidity globally, with estimated 495,000 deaths; in India HCV infection was estimated to be responsible for 37,000 deaths in 2015 (National Guidelines for Diagnosis and Management of Viral Hepatitis, 2018). HCV infection can be a cause of substantial economic burden if patients are not provided with accurate and timely treatment. Considering the alarming increase in the trend of HCV infection, National Viral Hepatitis Control Programme (NVHCP) was launched by the Ministry of Health and
Family Welfare, Government of India with the goal of ending viral hepatitis as a public health threat by 2030 in the country. Over the last decade $\mathrm{HCV}$ infection was predominantly treated with a combination of pegylated (PEG) - interferon (IFN)- $\alpha$ in combination with ribavirin (RBV), a nucleotide analogue. However, with the availability of new direct acting antiviral agents (DAAs), there has been been paradigm shift in management of $\mathrm{HCV}$ infected patients, with hope of eliminating $\mathrm{HCV}$ infection as a public health threat by 2030. Recently there has been an approval and adoption of pan genotypic DAAs. These pan genotypic drugs provide new opportunities for the public health response to HCV infection, with simplified procurement and no frequent laboratory monitoring. First pan genotypic regimen under NVHCP was combination of Sofosbuvir and Velpatas vir for a duration of 12 weeks.

Control of this infection requires a comprehensive approach including access to primary prevention of infection, enhanced screening against $\mathrm{HCV}$ in healthcare settings, and increased public awareness about the various modes of transmission and risk factors involved in spreading of infection. . Therefore this study was planned to detect prevalent genotypes of $\mathrm{HCV}$ in patients of Jammu region and their association with disease progression which eventually affect the selection of appropriate antiviral therapy.

\section{Bibliography}

1. Patel PH, Patel HK, Nerurkar AB. Study of Prevalence of Hepatitis C Virus (HCV) Infection in Patients attending Tertiary Care Hospital Valsad, Gujarat, India. Int J Curren Microbio App Sci 2017; 6(5):2783-87.

2. http:/www. who.int

3. Sy T, Jamal MM. Epidemiology of Hepatitis C Virus (HCV) Infection. Int $J$ Med Sci 2006; 3(2):41-06.

4. Ashfaq UA, Javed T, Rehman S, Nawaz Z, Riazuddin S. An overview of $\mathrm{HCV}$ 
molecular biology, replication and immune responses. Virol J 2011; 8:161.

5. Borgia SM, Hedskog C, Parhy B, Hyland RH, Stamm LM, Brainard DM, et al. Identification of a Novel Hepatitis C Virus Genotype From Punjab, India: Expanding Classification of Hepatitis C Virus Into 8 Genotypes. J Infect Dis 2018; 218(11):1722-29.

6. Smith DB, Bukh J, Kuiken C, Muerhoff AS, Rice CM, Stapleton JT et al. Expanded classification of hepatitis C virus into 7 genotypes and 67 subtypes: Updated criteria and genotype assignment web resource. Hepatology 2014; 59(1):318-27.

7. Satsangi S, Chawla YK. Viral hepatitis:Indian scenario. Med J Armed Forces India 2016; 72(3):204-10.

8. Raghuraman S, Abraham P, Sridharan G, Daniel HD, Ramakrishna BS, Shaji RV. HCV genotype 4-an emerging threat as a cause of chronic liver disease in India (south) patients. J Clin Virol 2004; 31(4) :253-58.

9. Christdas J, Sivakumar J, David J, Daniel H, Raghuraman S, Abraham P. Genotypes of hepatitis $\mathrm{C}$ virus in the Indian subcontinent: A decade long experience from a tertiary care hospital in South India. Indian J Med Microbiol 2013; 31(4):349-53.

10. Barman B, Bora K, Lynrah KG, Lyngdoh WV, Jamil M. Hepatitis C virus and its genotypes in chronic liver disease patients from Meghalaya, Northeast India. Indian J Med Microbiol 2018; 36(3):37680.

11. Kohara M, Tanaka T, TsukiyamaKohara K, Tanaka S, Mizokami M, Lau JYet al. Hepatitis $\mathrm{C}$ virus genotypes 1 and 2 respond to interferon-alpha with different virologic kinetics. J Infect Dis 1995; 172(4):934-38.
12. Kumar JP, Puttamaregowda

H. Distribution of hepatitis $\mathrm{C}$ virus genotypes in patients with chronic hepatitis $\mathrm{C}$ infection in Karnataka, South India . Int J Adv Med 2016; 3(4):905-07.

13. Tan SC and Yiap BC. DNA, RNA, and Protein Extraction: The Past and the Present. J Biomed Biotechnol 2009; 574398.

14. Alter MJ. Epidemiology of hepatitis C virus infection. World $J$ Gastroenterol 2007; 13(17):2436-41.

15. Deshpande RH, Wadde SK. Seroprevalence of $\mathrm{HCV}$ in blood donors status of blood donors seropositivity of $\mathrm{HCV}$ in Marathwada, India. J Pharma Biomed Sci 2012; 23(22):1-4.

16. Aziz H, Raza A, Murtaza S, Waheed Y, Khalid A, Irfan J et al. Molecular epidemiology of hepatitis $\mathrm{C}$ virus genotypes in different geographical regions of Punjab Province in Pakistan and a phylogenetic analysis. Int $J$ Infect Dis 2013; 17(4):e247-53.

17. Sharma M, Sehgal S, Sudhan SS, Razdan K, Pandita B, Sharma M. Epidemiology and Genotypes of Hepatitis C Virus: A First Study from Jammu (J\&K), India. J Gastrointest Infect 2017; 7(1):9-14.

18. Chakravarti A, Dogra G, Verma V, Srivastava AP. Distribution pattern of HCV genotypes \& its association with viral load. Indian J Med Res 2011; 133(3): 326-31.

19. Kumar S, Chawla YK, Ghosh S, Chakraborti A. Severity of Hepatitis C Virus (Genotype3) Infection Positively Correlates with Circulating MicroRNA122 in Patients Sera. Dis. Markers 2014, Article ID 435476, 6 pages https://doi.org/10.1155/2014/435476.

20. Shah NA, Parveen S, Kadla SA, Qureishi M, Farhat S, Iqbal J et al. Genotypes Distribution of Hepatitis C 
Virus in Indian Administered Kahmir; A Cross Sectional Study. J Hepatol Gastroenterol 2017; $1: 003$.

21. Al-Mahtab M. Past, Present and Future of Viral Hepatitis in Bangladesh. Euroasian J HepatoGastroenterol 2016; 6(1):43-44.

22. Khan AW, Nawab S, Nasim Z, Khan AH, Ahmad SI, Zahir F et al. Pattern of hepatitis $\mathrm{C}$ virus genotypes and subtypes circulating in war-stricken Khyber Pakhtunkhwa, Pakistan: Review of published literature. Asian Pac J Trop Med 2017; 10(11):1037-42.

23. Chaudhary S. Hepatitis $C$ in Nepal. $J$ Liver Res Disord Ther 2018; 4(1):47.

24. Chen Y, Yu C, Yin X, Guo X, Wu S, Hou J. Hepatitis $\mathrm{C}$ virus genotypes and subtypes circulating in Mainland China. Emerg Microbes Infect 2017; 6(11):e95.

25. Messina JP, Humphreys I, Flaxman A, Brown A, Cooke G, Pybus $O$ et al. Global Distribution and Prevalence of Hepatitis C Virus Genotypes. Hepatology 2015; 61(1):77-87.

26. Mohanraj U, Chavan YG, Pawar SR, Raut AD. Identification of hepatitis C virus genotypes and subtypes in patients from Maharashtra based on 5'UTR sequencing and analysis: a retrospective study. Int J Bioassays 2015; 4(12):460107.

27. Das BR, Kundu B, Khandapkar R, Sahni S. Geographical distribution of hepatitis $\mathrm{C}$ virus genotypes in India. Indian J Pathol Microbiol 2002; 45(3):323-28.

28. Prakash S, Shukla S, Ramakrishna V, Jain A. Distribution of hepatitis C genotypes in Uttar Pradesh, India ; rare genotype 4 detected. J Med Virol 2018; 90(12):1875-81.
29. Zachariah KC, Prakash A, Irudaya Rajan S. Return Emigrants in Kerala: Rehabilitation Problems and Development Potential. Working paper No. 3192001 Centre for Development Studies Thiruvananthapuram .

30. Chakravarti A, Dogra G, Verma V, Srivastava AP. Distribution pattern of HCV genotypes \& its association with viral load. Indian J Med Res 2011; 133(3): 326-31.

31. Rong X, Lu L, Wang J. Correlation of viral loads with HCV genotypes: higher levels of virus were revealed among blood donors infected with $6 \mathrm{a}$ strains. PLOS ONE 2012; $7:$ e52467.

32. Nabi SG, Zaffar G, Sheikh NI, Hassan K, Hassan U. Hepatitis $C$ virus genotypes: A plausible association with viral loads. Indian J Pathol Microbiol 2013; 56(4):384-87.

33. Rastin M, Mahmoudi M, Rezaee SA, Assarehzadegan MA, Tabasi N, Zamani S et al. Distribution of Hepatitis C virus genotypes in city of Mashhad, North-east of Iran. Indian J Med Microbiol 2014; 32(1):53-56. 